Note

\section{Measurement of Hydroxycinnamic Acid Ester Hydrolase Activity by the Change of UV Absorption*}

\author{
Shigemichi OKAMURA and \\ Masazumi WatanABE \\ Central Research Laboratories, \\ Kikkoman Corp., 399 Noda, \\ Noda-shi, Chiba 278, Japan
}

Received August 10, 1981

Koshu grape must and wine contain large amounts of hydroxycinnamic acid ester compounds, caffeoyl tartaric acid and $p$-coumaroyl tartaric acid, which have a bitter taste. $^{1,2)}$ Caffeoyl tartaric acid is a good substrate for enzymatic browning. ${ }^{2)}$

In a previous study ${ }^{3)}$ we found the enzyme (hydroxycinnamic acid ester hydrolase: $\mathrm{HCEH}$ ) hydrolyzing these hydroxycinnamic acid ester compounds in a wheat bran culture of Aspergillus japonicus ATCC 20236 and investigated the productive conditions, properties and application of $\mathrm{HCEH}$ to wine making. Then $\mathrm{HCEH}$ activity expressed as the amount of hydrolyzed chlorogenic acid (3-caffeoyl quinic acid) was determined by highperformance liquid chromatography. However, with this method many samples cannot be tested at one time. A simple and accurate assay method for the enzyme is desirable for its purification and elucidation of the enzyme's properties.

The present communication deals with a convenient method for determining $\mathrm{HCEH}$ activity by the change of UV absorption due to the hydrolysis of chlorogenic acid.

1. Deciding the wavelength. UV spectra of chlorogenic acid and the completely hydrolyzed hydrolyzate are shown in Fig. 1. The UV spectrum of the hydrolyzate of chlorogenic acid was shifted to the short wavelength side compared to that of chlorogenic acid. The difference spectrum ( $\triangle \mathrm{OD}$ ) between chlorogenic acid and the hydrolyzate obtained from Fig. 1 showed a maximum at $340 \mathrm{~nm}$ (Fig. 2). However, the molecular absorption coefficient of chlorogenic acid is also large at this wavelength.

When the enzyme activity is measured at the wavelength where the molecular absorption coefficient of the substrate is large, the concentration of the substrate must be low, because absorbance of below 0.8 of the solution measured is profitable. But to assay the enzyme amount in a wider range, a higher concentration of the substrate is desirable.

\footnotetext{
* Hydroxycinnamic Acid Ester Hydrolase of Microorganisms. Part II.
}

That is to say, at the specified wavelength, a larger absolute absorption value in the difference spectrum and a smaller molecular absorption coefficient of the substrate are necessary. Then the ratio $(K)$ of the absolute absorption value in the difference spectrum to the molecular absorption coefficient of chlorogenic acid should be larger. As shown in Fig. 2, a wavelength of around $272 \mathrm{~nm}$ or of over $350 \mathrm{~nm}$ satisfies the above conditions.

On the other hand, a more sensitive assay can be achieved, if the absolute absorption value in the difference spectrum is larger. Thus, the wavelength of $350 \mathrm{~nm}$, where absorbance of enzyme protein is very little, was selected

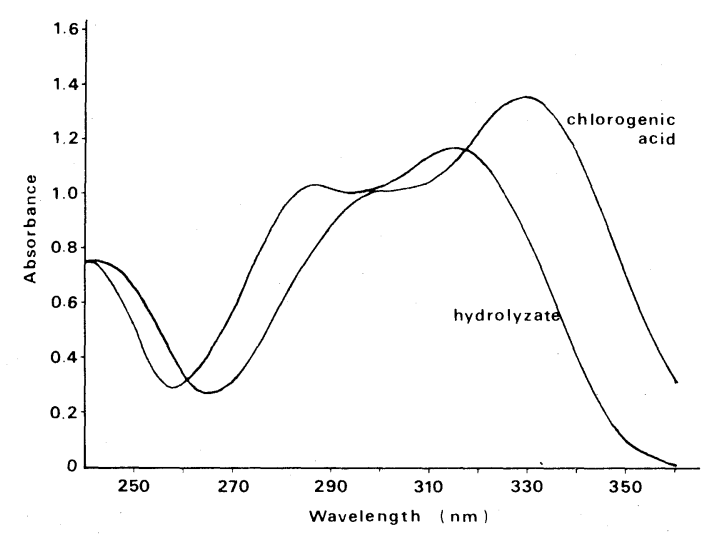

FIG. 1. UV Absorption Spectra of the Substrate and Its Hydrolyzate.

The enzyme solution $(0.03 \mathrm{ml})$ was added to the reaction mixture $(0.5 \mathrm{ml}$ of $0.05 \mathrm{M}$ phosphate buffer, $\mathrm{pH} 6.5)$ containing $0.75 \mu \mathrm{mol}$ of chlorogenic acid, and the mixture was incubated at $30^{\circ} \mathrm{C}$. After chlorogenic acid was hydrolyzed completely, $10 \mathrm{ml}$ of $80 \%$ methanol was added to this reaction mixture. The UV spectra of the methanol solutions were taken with a HITACHI type 323 recording spectrophotometer. The blank sample was prepared in the same way with distilled water instead of enzyme solution.

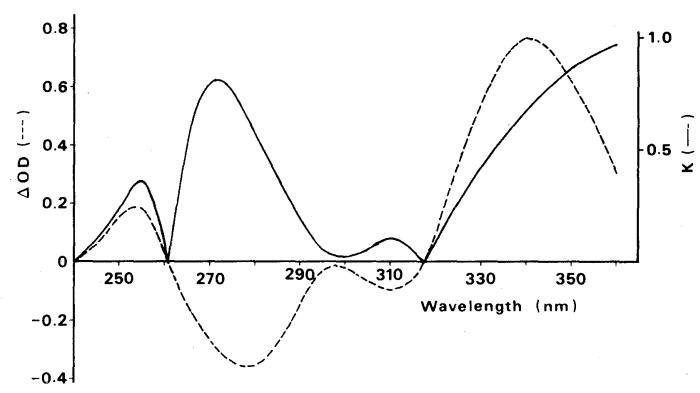

FIG. 2. Difference Spectrum between Chlorogenic Acid and Its Hydrolyzate and ' $K$ ' Value at Each Wavelength. ---, difference spectrum; - $K$ value, the ratio of the absolute value of absorbance difference between chlorogenic acid and its hydrolyzate to the molecular absorption coefficient of chlorogenic acid. 


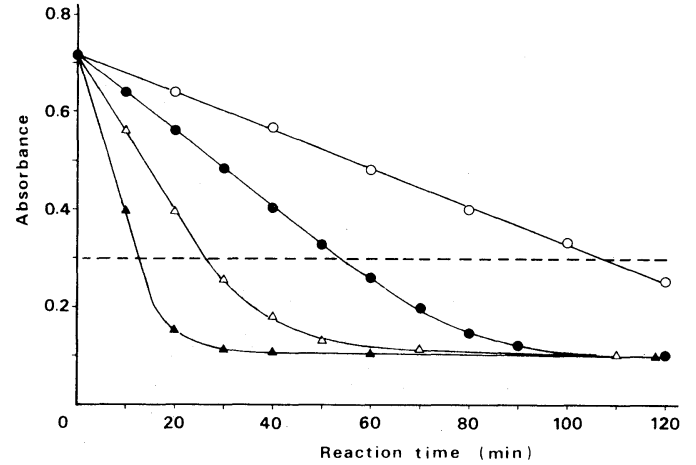

FIG. 3. Change in Absorbance during Hydrolysis of Chlorogenic Acid.

See the legend to Fig. 1 for the conditions of the enzyme reaction. Enzyme solution denatured at $70^{\circ} \mathrm{C}$ for $10 \mathrm{~min}$ was used for a blank test.

Enzyme concentration: $\boldsymbol{\Delta}, 1$ (about 1.3 units $/ \mathrm{ml}$ ); $\triangle, 1 / 2$; - $1 / 4 ; \bigcirc, 1 / 8$.

for the assay system for HCEH.

2. Measurement procedure. Phosphate buffer solution $(0.05 \mathrm{M}, \mathrm{pH} 6.5), 0.5 \mathrm{ml}$ containing $0.75 \mu \mathrm{mol}$ of chlorogenic acid (substrate concentration: $530 \mathrm{mg} / \mathrm{liters}$ ), was placed in a test tube $(17.5 \mathrm{~mm} \times 130 \mathrm{~mm})$ and $30 \mu \mathrm{lof}$ purified enzyme solution was added to start the reaction. After incubation at $30^{\circ} \mathrm{C}$ for the specified time, $10 \mathrm{ml}$ of $80 \%$ methanol was added to stop the reaction and the absorbance at $350 \mathrm{~nm}$ of the mixture was measured. The heat denatured $\left(70^{\circ} \mathrm{C}, 10 \mathrm{~min}\right)$ enzyme solution was used for a blank test.

Since the optimal $\mathrm{pH}$ for $\mathrm{HCEH}$ activity was 6.0 to $7.0,{ }^{3)}$ phosphate buffer of $\mathrm{pH} 6.5$ was adopted. Salts of the buffer and the enzyme protein were not precipitated by methanol. The absorbance did not change over 6 hours.

As shown in Fig. 3, the changes in the absorbance during the enzyme reaction were linear in the range of 0.72 to 0.30 being independent of the enzyme concentration. The enzyme reaction was carried out ten times with the enzyme preparations of 4 different concentrations shown in Fig. 3, so that the change in absorbance was in the range of 0.2 to 0.3 . The standard deviation(s) of the absorbance change was less than 0.0035 for each enzyme concentration and the standard error $(100 \cdot \mathrm{s} / \Delta \mathrm{OD})$ was less than $100 \cdot 0.0035 / 0.2$, i.e., $1.8 \%$.

The assay of HCEH by this method was also possible with a crude enzyme preparation generally colored brown. However, this method is not applicable for the crude enzyme with high polyphenol oxidase activity because chlorogenic acid can serve as a substrate for the oxidase.

3. Unit of enzyme activity. One unit of HCEH activity was defined as the amount of the enzyme which hy-

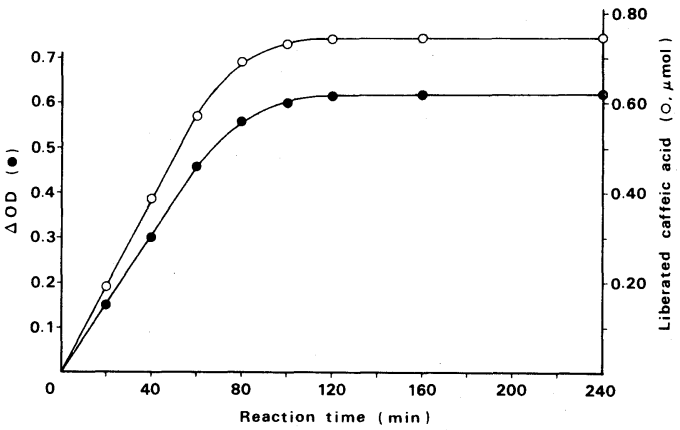

FIG. 4. Time Course of $\triangle \mathrm{OD}$ and the Amount of Liberated Caffeic Acid during Enzyme Reaction.

See the legend to Fig. 1 for the conditions of the enzyme reaction. About 0.32 units $/ \mathrm{ml}$ of enzyme was used. Denatured enzyme solution was used for a blank test. The amounts of liberated caffeic acid were determined by HPLC with $30 \mu$ l of each methanol solution.

drolyzed one $\mu \mathrm{mol}$ of the ester bond of the substrate in one minute at $30^{\circ} \mathrm{C}$ under the above conditions. The unit of the enzyme can be obtained from the following equation.

$$
u=C \cdot \frac{\Delta \mathrm{OD}}{\Delta \mathrm{OD}_{\mathrm{c}}} \cdot \frac{1}{\Delta t}
$$

where

$C$ : ester bond concentration of the substrate

$\triangle \mathrm{OD}$ : change in absorbance during incubation

$\Delta \mathrm{OD}_{\mathrm{c}}$ : change in absorbance for complete hydrolysis of the substrate from the start of the reaction

$\Delta t$ : reaction time $(\mathrm{min})$

Since $C$ is $0.75 \mu \mathrm{mol}$ because chlorogenic acid contains one $\mathrm{mol}$ of ester bond per one mol and $\Delta \mathrm{OD}_{\mathrm{c}}$ is 0.62 under the standard assay conditions, the above equation is transformed as below.

$$
\begin{aligned}
u & =0.75 \cdot \frac{\Delta \mathrm{OD}}{0.62} \cdot \frac{1}{\Delta t} \\
& =1.21 \cdot \frac{\Delta \mathrm{OD}}{\Delta t}
\end{aligned}
$$

Figure 4 shows the relationship between the measurement of HCEH activities by this method and by highperformance liquid chromatography analysis. The change in absorbance at $350 \mathrm{~nm}$ and the liberation of caffeic acid seemed to be directly correlated.

Therefore, the proposed method can be used as a convenient method with appropriate accuracy to determine the catalytic rate of $\mathrm{HCEH}$.

Acknowledgments. The authors wish to express their thanks to Dr. N. Iguchi and Dr. F. Yoshida for their encouragement and to Dr. S. Nasuno for his helpful advice. 


\section{REFERENCES}

1) S. Okamura and M. Watanabe, Nippon Nôgeikagaku Kaishi, 53, 165 (1979).
2) S. Okamura and M. Watanabe, Agric. Biol. Chem., 45, 2063 (1981).

3) S. Okamura and M. Watanabe, Nippon Nôgeikagaku Kaishi, 55, 1099 (1981). 